\title{
Distribusi tangkapan pada jaring insang cendro di perairan pantai bagian timur Kabupaten Kepulauan Sangihe
}

\author{
Catch distribution on cendro gill net in the coastal waters of eastern Sangihe Islands Regency
}

\author{
ISROJATY J. PARANSA*, AMINADAB FAAM dan JOHNNY BUDIMAN \\ Program Studi Pemanfaatan Sumberdaya Perikanan, Fakultas Perikanan dan Ilmu Kelautan, \\ Universitas Sam Ratulangi, Manado 95115
}

\begin{abstract}
Crocodile fish (Tylosorus sp) is one of the important economic resources in Indonesia, which is spread in the waters of eastern Indonesia. These fish include oily fish were elusive because the movement is very agile, rarely caught with a net, generally caught by kite fishing, but particularly in Sangihe Islands in Simueng Village fishermen catch these fish using gill nets, known as soma sako or soma solong. Based on 10 fishing trips, the first piece of the net caught $1542(38.88 \%)$ fish and the second caught $2424(38.30 \%)$ fish, while the third piece caught $905(22.81 \%)$ fish. These indicated that the fish trying to escape from the bottom of the nets while the fish is known as the kinds of fish clustered near the surface of the water.
\end{abstract}

Keywords: fish, cendro, net, escape, maximum width.

\begin{abstract}
ABSTRAK
Ikan cendro (Tylosorus sp) termasuk salah satu sumberdaya ekonomis penting di Indonesia, yang menyebar di perairan Indonesia bagian Timur. Ikan ini termasuk ikan pelagis yang sulit ditangkap karena pergerakan sangat gesit, jarang tertangkap dengan jaring, umumnya tertangkap dengan pancing layang-layang. Namun, di Kabupaten Kepulauan Sangihe khususnya di Desa Simueng nelayan menangkap ikan ini dengan menggunakan jaring insang yang dikenal dengan soma sako atau soma solong. Berdasarkan 10 trip penangkapan, pada lembaran pertama yang tertangkap adalah adalah 1542 ekor $(38,88 \%)$ dan lembar kedua sebanyak 2424 ekor (38,30 \%), sedangkan lembar jaring ketiga adalah 905 ekor (22,81\%). Indikasi ini menunjukkan bahwa ikan berusaha meloloskan diri dari bagian bawah jaring sementara ikan jenis ini dikenal sebagai ikan yang bergerombol di dekat permukaan air.
\end{abstract}

Kata-kata kunci: ikan, cendro, jaring, meloloskan diri, lebar maksimum

\section{PENDAHULUAN}

Ikan cendro (Tylosorus $s p$ ) di Sulawesi Utara khususnya di Kabupaten Kepulauan Sangihe dikenal dengan nama solong atau ikan sako. Ikan ini termasuk ikan pelagis yang sulit ditangkap karena pergerakan sangat gesit, jarang tertangkap dengan jaring, umumnya tertangkap dengan pancing layang-layang (Nontji, 2007). Namun, di Kabupaten Kepulauan Sangihe khususnya di Desa Simueng nelayan menangkap ikan ini dengan menggunakan jaring insang yang dikenal dengan soma sako atau soma solong.

Data hasil tangkapan ikan-ikan pelagis yang dikeluarkan oleh Pemerintah Kabupaten

\footnotetext{
*Penulis untuk penyuratan; email: iparansa@yahoo.com
}

Kepulauan Sangihe (2010) belum menginformasikan tangkapan ikan cendro. Padahal ikan cendro termasuk salah satu sumberdaya ekonomis penting di Indonesia, di samping ikan cakalang ikan tuna, ikan kakap, ikan kembung, ikan tembang, ikan kecil dan ikan besar lainnya.yang menyebar di perairan Indonesia bagian timur.

Jaring insang ikan cendro atau soma sako yang dimiliki oleh nelayan Desa Simueng menggunakan kayu kahuang (kayu kang) pada kedua ujung kiri dan kanan alat yang berfungsi mempermudah proses penarikan, di mana bagian tali pemberat dan tali pelampung dapat ditarik secara bersamaan dengan kecepatan sama sampai dengan kayu kahuang dinaikkan di atas perahu. 